\title{
Cepharanthine exhibits a potent anticancer activity in p53-mutated colorectal cancer cells through upregulation of $\mathbf{p 2 1}{ }^{\text {Waf } 1 / C i p 1}$
}

\author{
ARKORNNUT RATTANAWONG ${ }^{1}$, VILAWAN PAYON ${ }^{1}$, WACHAREE LIMPANASITTIKUL ${ }^{1}$, \\ CHATIKORN BOONKRAI ${ }^{2}$, APIWAT MUTIRANGURA ${ }^{3}$ and PIYANUCH WONGANAN ${ }^{1}$ \\ ${ }^{1}$ Department of Pharmacology, ${ }^{2}$ Systems Biology Center, Research Affairs and ${ }^{3}$ Department of Anatomy, \\ Faculty of Medicine, Chulalongkorn University, Bangkok 10330, Thailand
}

Received May 23, 2017; Accepted October 25, 2017

DOI: 10.3892/or.2017.6084

\begin{abstract}
Cepharanthine (CEP), a biscoclurine alkaloid isolated from Stephania cepharantha Hayata, has demonstrated anticancer activity in several different types of cancer cells. Colorectal cancer (CRC) is one of the most common cancers in both men and women. Mutated p53 in CRC was reported to be associated with resistance to commonly used chemotherapeutic agents including, 5-fluorouracil, oxaliplatin and irinotecan. Many studies reported that mutation of p53 induced chemoresistance through several mechanisms, including induction of drug efflux, disruption of cell cycle regulation, evasion of apoptosis and upregulation of DNA repair. This study aimed to evaluate the anticancer activity of CEP in p53 mutant versus p53 wild-type colorectal cancer cells and determine its underlying mechanisms of action. Our results showed that CEP induced colorectal cancer cell death in a concentration-dependent manner. Remarkably, CEP was more effective in controlling the growth of the p53 mutant colorectal cancer cell lines, HT-29 and SW-620, than the p53 wild-type colorectal cancer cell lines, COLO-205 and HCT-116. Further studies on the underlying mechanisms revealed that CEP could induce cell cycle arrest and apoptosis in both HT-29 and COLO-205 cells. Treatment with CEP dramatically increased $\mathrm{p} 21^{\mathrm{Waf} 1 / \mathrm{Cip} 1}$ expression levels of the $\mathrm{p} 53$ mutant cell line HT-29 and to a lesser extent, the p53 wild-type cell line COLO-205. In addition, cyclin A and Bcl-2 expression levels of both cell lines were significantly downregulated following treatment with CEP. CEP also induced ROS formation in colorectal cancer cells. Taken together, we concluded that CEP effectively induced cell cycle arrest and apoptosis which may be mediated through upregulation of $\mathrm{p} 21^{\text {Waf1/Cip1 }}$,
\end{abstract}

Correspondence to: Dr Piyanuch Wonganan, Department of Pharmacology, Faculty of Medicine, Chulalongkorn University, 1873 Rama IV Road, Pathumwan, Bangkok 10330, Thailand

E-mail: piyanuch.w@chula.ac.th

Key words: cepharanthine, colorectal cancer, cell cycle arrest, apoptosis, p53, p21 ${ }^{\text {Waf/Cipl }}$ downregulation of cyclin A and Bcl-2 and induction of ROS production in colorectal cancer cells. These findings suggested that CEP could potentially be a novel anticancer agent for p53 mutant colorectal cancer cells which are often resistant to current chemotherapeutic agents.

\section{Introduction}

Colorectal cancer (CRC) is one of the most commonly diagnosed cancer in both men and women and is the second leading cause of cancer-associated death worldwide (1). Currently, the treatment options for CRC include surgery, chemotherapy, radiotherapy and targeted therapies, which depend on stage of the disease and physical health of the patient. The chemotherapeutic agents commonly used in CRC treatments are 5-fluorouracil, oxaliplatin and irinotecan (2). Although combination therapy of these drugs has improved response rate and progression-free survival, its application is often limited due to acquired drug resistance which can occur in nearly all patients with CRC (3). Therefore, novel therapeutic compounds and strategies to overcome drug resistance are urgently needed.

Tumor suppressor p53 plays an important role in the regulation of DNA repair, cell cycle arrest, and apoptosis in the presence of cellular stress. Mutations in p53, the most common genetic change in human cancer, have been detected in $\sim 40-50 \%$ of sporadic CRC (4). Mutant p53 has been shown to be involved in proliferation, invasion, migration, angiogenesis and cell survival. It is also responsible for drug resistance of cancer cells (5). Mutant p53 induced chemoresistance through several mechanisms, including induction of drug efflux, disruption of cell cycle regulation, evasion of apoptosis and upregulation of DNA repair (6). It has been reported that mutated p53 in CRC is associated with resistance to commonly used chemotherapeutic agents, including, 5-FU, doxorubicin, oxaliplatin and irinotecan (7-9). Therefore, finding a novel anticancer compound that remains effective without p53 chemoresistance may offer a potential strategy for the treatment of chemoresistant cancer cells.

Cepharanthine (CEP), a biscoclaurine alkaloid extracted from Stephania cepharantha Hayata, possesses various biological activities such as anti-inflammatory, anti-malarial, 
anti-HIV-1, anti-oxidant, and anti-allergic (10). Notably, CEP has been found to exert anticancer activities against several types of cancer cells such as leukemia, oral squamous cell carcinoma, hepatocellular carcinoma, myeloma, cholangiocarcinoma, osteosarcoma, cervical adenocarcinoma, nasopharyngeal carcinoma and non-small cell lung cancer both in vitro and in vivo (11-21). It has been reported that CEP inhibited tumor growth through numerous mechanisms, including induction of host immune responses, inhibition of NF- $\kappa \mathrm{B}$ and STAT3 signaling pathways and reduction of angiogenesis by inhibiting expression of two major pro-angiogenic factors, vascular endothelial growth factor (VEGF) and interleukin-8 (IL-8) (16,18,22-24). Mechanistic studies revealed that CEP induced apoptosis via activating caspase- 3 and -9 , stimulating pro-apoptotic signaling pathways such as JNK, ERK and p38 MAPK pathways, inhibiting antiapoptotic gene Bcl-xl expression and inducing oxidative stress $(12,14-16,18,24,25)$. Moreover, CEP was found to induce cell cycle arrest by downregulating the expression of cyclin D1, CDK-6 and c-Myc $(15,18)$. Remarkably, CEP has been found to induce cell cycle arrest of adenosquamous cell carcinoma carrying p53 mutation (25).

To the best of our knowledge, there were only a few reports of antitumor effect of CEP in CRC cells (26). More importantly, the mechanisms underlying anticancer effect of CEP in CRC have never been investigated. In the present study, we therefore evaluated the anticancer activity of CEP using a p53 wild-type human colorectal cancer cell line, COLO-205, and a p53 mutant human colorectal cancer cell line, HT-29, and determined its underlying mechanisms of action.

\section{Materials and methods}

Chemical reagents. Cepharanthine was from Abcam (Cambridge, UK). Bovine serum albumin (BSA), dimethyl sulfoxide(DMSO), hydrogen peroxide $\left(\mathrm{H}_{2} \mathrm{O}_{2}\right), \mathrm{N}$-acetylcysteine (NAC), oxaliplatin, SN-38, trypan blue, 5-fluorouracil, 3-(4,5-dimethylthiazol-2-yl)-2,5-diphenyltetrazolium bromide (MTT) were from Sigma-Aldrich (St. Louis, MO, USA). Propidium iodide (PI) was from Santa Cruz Biotechnology (Dallas, TX, USA). Chloroform, ethanol and 2-propanolol were from Merck (Kenilworth, NJ, USA). Nuclease-free water was from Qiagen (Hilden, Germany).

Cell lines and culture. Human colorectal cancer cell lines HT-29 and COLO-205 were from American Type Culture Collection (Manassas, VA, USA) whereas SW-620 and HCT-116 were kindly provided by Dr Amornpun Sereemaspun (Chulalongkorn University, Thailand). HT-29 and SW-620 were grown in Dulbecco's modified Eagle's minimal essential medium (DMEM; Gibco, Grand Island, NY, USA) supplemented with $10 \%$ fetal bovine serum (FBS; Gibco), $100 \mathrm{U} / \mathrm{ml}$ penicillin and $100 \mu \mathrm{g} / \mathrm{ml}$ streptomycin (Gibco). COLO-205 and HCT-116 were cultured in RPMI-1640 medium containing $10 \% \mathrm{FBS}, 100 \mathrm{U} / \mathrm{ml}$ penicillin and $100 \mu \mathrm{g} / \mathrm{ml}$ streptomycin. The cells were maintained at $37^{\circ} \mathrm{C}$ in a humidified $5 \% \mathrm{CO}_{2}$ atmosphere.

Cell viability assay. Cell viability was determined by using the MTT reduction assay. Briefly, cells were seeded in 96-well plates at a density of $5 \times 10^{3}$ cells/well. After overnight incubation, the cells were treated with 5-FU, oxaliplatin, SN-38 or CEP at $0.01,0.1,1,10$ and $100 \mu \mathrm{M}$ for $48 \mathrm{~h}$. Thereafter, MTT solution was added and incubated for additional $4 \mathrm{~h}$. The medium was removed and $200 \mu \mathrm{l}$ of DMSO was added to each well. The absorbance of the converted dye was measured at a wavelength of $570 \mathrm{~nm}$ using LabSystems Multiskan MS microplate reader (Thermo Scientific, Vantaa, Finland).

Cell cycle analysis. HT-29 and COLO-205 cells were seeded in 6-well plates at a density of $3 \times 10^{5}$ cells/well and incubated overnight. HT-29 cells were treated with 5,10 , and $20 \mu \mathrm{M}$ of CEP or $0.2 \%$ DMSO (solvent control) whereas COLO-205 cells were treated with 10,20 and $40 \mu \mathrm{M}$ of CEP or $0.2 \%$ DMSO. After 12, 24 or $36 \mathrm{~h}$ of incubation, the cells were washed with phosphate-buffered saline (PBS), harvested by trypsinization and centrifuged at 1,500 rpm for $5 \mathrm{~min}$. The cell pellets were washed with cold PBS and fixed with $70 \%$ ethanol for $20 \mathrm{~min}$ at $-20^{\circ} \mathrm{C}$. The cells were then washed with cold PBS and incubated with $500 \mu \mathrm{l}$ of assay buffer containing $5 \mu \mathrm{l}$ of $4 \mathrm{mg} / \mathrm{ml}$ RNase A at room temperature. After 30-min incubation, the cells were stained with $5 \mu \mathrm{l}$ of $0.05 \mu \mathrm{g} / \mathrm{ml}$ PI for another $30 \mathrm{~min}$ at room temperature in the dark. DNA content of the stained cells was analyzed using BD LSR II flow cytometer.

Real-time RT-PCR. Total RNA was isolated using TRIzol reagent (Life Technologies) according to the manufacturer's instructions. RNA concentration and purity was determined using NanoDrop ND-2000 (Thermo Scientific, Rockford, IL, USA). RNA (500 ng) was reverse-transcribed into cDNA using Improm II $^{\mathrm{TM}}$ Reverse Transcription system (Promega, Madison, WI, USA). Amplification of target genes was carried out on StepOnePlus ${ }^{\mathrm{TM}}$ Real-Time PCR system (Applied Biosystems, Waltham, MA, USA) using SYBR GreenER ${ }^{\mathrm{TM}}$ qPCR Supermix (Life Technologies) and the primers listed in Table I. Expression of the gene of interest was normalized to the glyceroldehyde-3-phosphate dehydrogenase (GAPDH) and relative expression was calculated using the $\Delta \Delta \mathrm{CT}$ method.

Western blotting. Cell lysates were prepared by homogenizing cells in RIPA lysis buffer (Thermo Fisher Scientific) containing protease inhibitors (Sigma). Protein concentration of supernatants was determined by a microplate assay with the Bio-Rad DC Protein assay reagents (Hercules, CA, USA) using bovine serum albumin as a standard. Twenty micrograms of protein lysate were separated on an $8 \%$ sodium dodecyl sulfate polyacrylamide gel electrophoresis (SDS-PAGE) and then transferred to a PVDF membrane. The membrane was blocked in 3\% non-fat dry milk (NFDM) and then incubated with antibodies against p21 ${ }^{\text {Waf1/Cip1 }}$ (dilution 1:1,000, 2947; Cell Signaling Technology, Danvers, MA, USA), cyclin A2 (dilution 1:2,000, 4656; Cell Signaling Technology), cyclin D1 (dilution 1:1,000, 2922; Cell Signaling Technology) or $\beta$-actin (dilution 1:1,000, 4970; Cell Signaling, Technology) overnight at $4^{\circ} \mathrm{C}$. The membrane was then washed and incubated with HRP-linked secondary antibody (Cell Signaling Technology) for $1 \mathrm{~h}$ at room temperature. Protein bands were detected using Luminata $^{\mathrm{TM}}$ Cescendo Western HRP substrate (Millipore, Billerica, MA, USA) and analyzed using Image Studio 
Table I Sequences of primers used for real-time RT-PCR analysis.

\begin{tabular}{ll}
\hline $\begin{array}{l}\text { Target } \\
\text { genes }\end{array}$ & \multicolumn{1}{c}{ Primer sequences } \\
\hline Bcl-2 & F: 5'-TCA TGT GTG TGG AGA GCG TCA A-3' \\
& R: 5'-CTA CTG CTT TAG TGA ACC TTT TGC-3' \\
Bcl-xl & F: 5'-TTG GAC AAT GGA CTG GTT GA-3' \\
& R: 5'-GTA GAG TGG ATG GTC AGT G-3' \\
Bax & F: 5'-GAC GAA CTG GAC AGT AAC ATG-3' \\
& R: 5'-AGG AAG TCC AAT GTC CAG CC-3' \\
Bak & F: 5'-ATG GTC ACC TTA CCT CTG CAA-3' \\
& R: 5'-TCA TAG CGT CGG TTG ATG TCG-3' \\
Cyclin A & F: 5'-CTG CTG CTA TGC TGT TAG CC-3' \\
& R: 5'-TGT TGG AGC AGC TAA GTC AAA A-3' \\
Cyclin D & F: 5'-TTG TTG AAG TTG CAA AGT CCT GG-3' \\
& R: 5'-ATG GTT TCC ACT TCG CAG CA-3' \\
Cyclin E & F: 5'-TCC TGG ATG TTG ACT GCC TT-3' \\
& R: 5'-CAC CAC TGA TAC CCT GAA ACC T-3' \\
p21 & F: 5'-CCT GTC ACT GTC TTG TAC CCT-3' \\
& R: 5'-GCG TTT GGA GTG GTA GAA ATC T-3' \\
GAPDH & F: 5'-AAG GTC GGA GTC AAC GGA TTT GGT-3' \\
& R: 5'-ATG GCA TGG ACT GTG GTC ATG AGT-3'
\end{tabular}

$\mathrm{F}$, forward. R, reverse.

software (LI-COR, Lincoln, NE, USA). $\beta$-actin was used as the loading control for protein normalization.

Immunofluorescence staining. After growing HT-29 cells on 8-well Lab-Tek chamber slides (Thermo Fisher Scientific) overnight, the cells were treated with CEP at various concentrations for $24 \mathrm{~h}$. The cells were then fixed in $4 \%$ paraformaldehyde for $15 \mathrm{~min}$ at room temperature. After washing with PBS, the cells were permeabilized with $0.25 \%$ Triton X-100 for 10 min at room temperature. Thereafter, the cells were washed and incubated with blocking solution containing $2 \%$ normal goat serum (Abcam) and 1\% bovine serum albumin for $20 \mathrm{~min}$ at room temperature. The cells were then washed with PBS and incubated with a p21 $1^{\text {Waf1/Cip1 }}$ rabbit antibody (dilution 1:800, 2947; Cell Signaling Technology) overnight at $4^{\circ} \mathrm{C}$ followed by incubation with Alexa Fluor 488 conjugated goat antirabbit secondary antibody (Invitrogen) for $30 \mathrm{~min}$ at room temperature in the dark. The cells were washed, mounted using fluoroshield mounting medium with DAPI (Abcam) and observed with an LSM 800 Confocal Laser Scanning Microscope (Zeiss, Oberkochen, Germany).

Measurement of ROS generation. Intracellular ROS was quantified using membrane-permeable fluorescent probe dichlorodihydrofluorescein diacetate (DCFH-DA). Cells were seeded in 96 -well plates at a density of $5 \times 10^{3}$ cells. After overnight incubation, the culture medium was replaced with $100 \mu 1$ of Hank's buffered salt solution (HBSS) containing $10 \mu \mathrm{M}$ DCFH-DA and incubated for $30 \mathrm{~min}$ at $37^{\circ} \mathrm{C}$ in the dark.
Table II. IC $_{50}$ of anticancer agents and cepharanthine (CEP) in HT-29 and COLO-205 cells.

\begin{tabular}{lrr}
\hline & \multicolumn{2}{c}{$\mathrm{IC}_{50}(\mu \mathrm{M})$} \\
\cline { 2 - 3 } Drug & \multicolumn{1}{c}{ HT-29 } & COLO-205 \\
\hline 5-Fluorouracil & $12.64 \pm 2.61$ & $2.67 \pm 1.20$ \\
Oxaliplatin & $2.83 \pm 0.32$ & $1.23 \pm 0.45$ \\
SN-38 & $2.40 \pm 0.37$ & $1.20 \pm 0.14$ \\
CEP & $5.18 \pm 1.23$ & $20.74 \pm 1.47$
\end{tabular}

The cells were washed with PBS and incubated with various concentrations of CEP for $1 \mathrm{~h}$. The cells were then washed with cold PBS and suspended in $200 \mu \mathrm{l}$ of $1 \%$ Triton X-100. The fluorescence intensity was measured using a fluorescent microplate reader (Thermo Scientific) at an excitation wavelength of $485 \mathrm{~nm}$ and an emission wavelength of $535 \mathrm{~nm}$.

Statistical analysis. Data are presented as mean \pm standard error of mean (SEM) from at least three independent experiments. Statistical analysis was carried out by one-way analysis of variance (ANOVA) followed by a Bonferroni/Dunn post hoc comparison test. P-values $<0.05$ were considered statistically significant.

\section{Results}

Cepharanthine exhibits a potent anticancer activity in p53-mutated colorectal cancer cells. Initially, we evaluated the cytotoxicity of cepharanthine (CEP) compared to the most common chemotherapeutic agents for CRC, including 5-fluorouracil, oxaliplatin, and SN-38 (an active metabolite of irinotecan), in a p53 mutant HT-29 cells and a p53 wild-type COLO-205 cells. As shown in Fig. 1A, all four compounds decreased cell viability of both cell lines in a concentration-dependent manner. However, the $\mathrm{IC}_{50}$ values illustrated that the COLO-205 cells were more susceptible to the three FDA-approved anticancer drugs than the HT-29 cells (Table II). Interestingly, CEP was more toxic to the HT-29 cells than the COLO-205 cells as evidenced by a $\sim$-fold lower $\mathrm{IC}_{50}$ value.

To further confirm the anticancer activity of CEP in p53 mutant colorectal cancer cells, we determined the cell viability of 4 human colorectal cancer cell lines treated with CEP at 2.5, 5, 10, 20 and $40 \mu \mathrm{M}$ for $48 \mathrm{~h}$. These cell lines were p53 mutant CRC cells; HT-29 and SW-620 and p53 wild-type CRC cells; HCT-116 and COLO-205. As shown in Fig. 1B, CEP decreased the viability of HT-29, SW-620, HCT-116 and COLO-205 cells in a concentration-dependent manner. However, HT-29 and SW-620 with p53 mutations were more susceptible to the cytotoxic effect of CEP than HCT-116 and COLO-205 cells with wild-type p53 (Fig. 1C). These results suggested that CEP was very effective in controlling the growth of cancer cells harboring p53 mutations.

Cepharanthine induces cell cycle arrest and apoptosis in both p53-mutant and p53 wild-type colorectal cancer cells. 
A
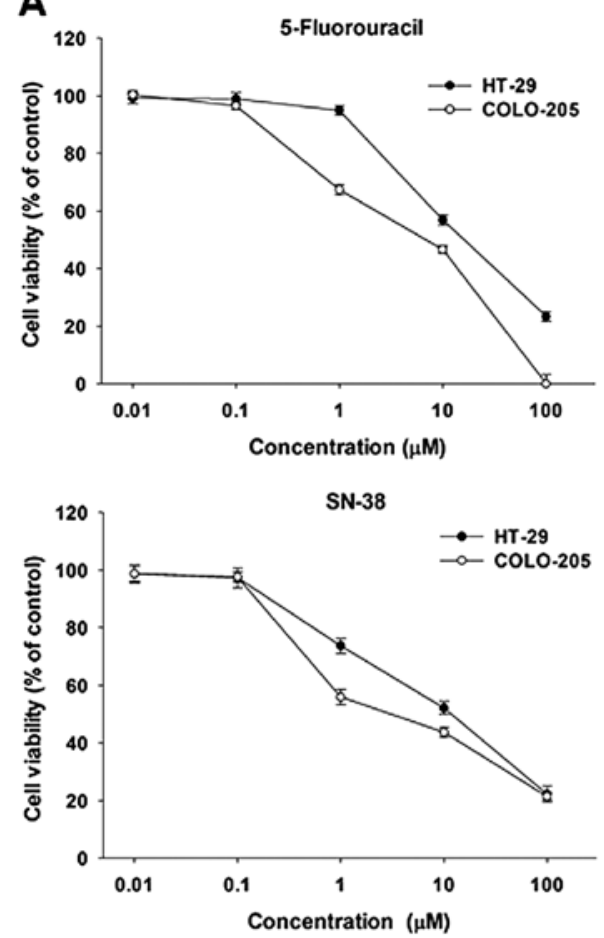

B

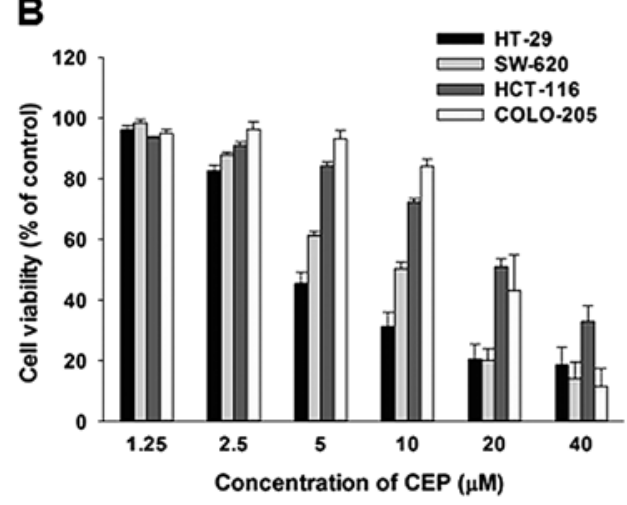

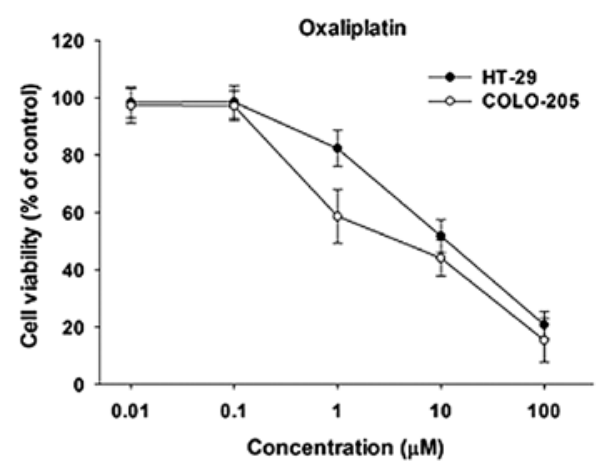

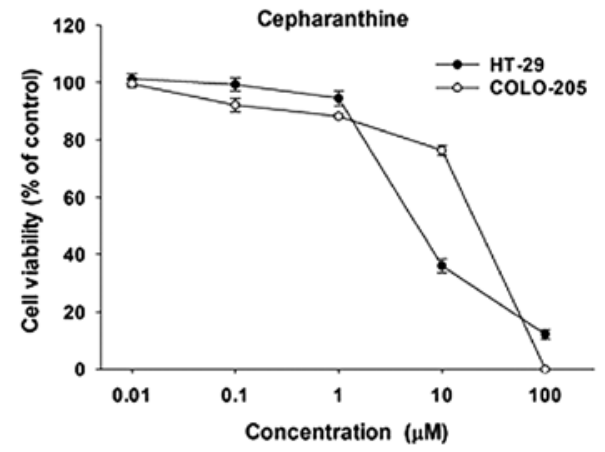

C

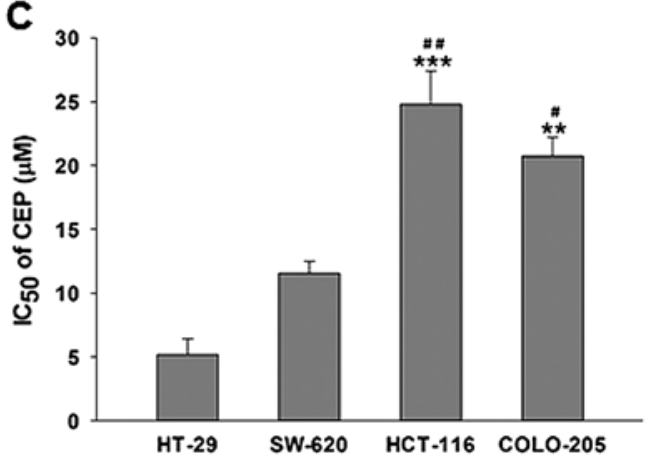

Figure 1. CEP exhibits a potent anticancer activity in p53-mutated colorectal cancer cells. (A) Cytotoxicity of 5-FU, oxaliplatin, SN-38 and CEP on HT-29 and COLO-205 cells. Cells were treated with indicated compounds for $48 \mathrm{~h}$ and cell viability was evaluated using $\mathrm{MTT}$ assay. (B) $\mathrm{Cytotoxicity}$ and $(\mathrm{C}) \mathrm{IC}_{50}$ of CEP on four CRC cell lines. Cells were treated with CEP for $48 \mathrm{~h}$ and cell viability was determined using MTT assay. ${ }^{* *} \mathrm{p}<0.01$ and ${ }^{* * *} \mathrm{p}<0.001 \mathrm{vs}$. HT-29; ${ }^{\#} \mathrm{p}<0.05$ and ${ }^{\# \#} \mathrm{p}<0.01$ vs. SW-620.

We then determined whether the growth-inhibitory effect of CEP is related to cell cycle arrest. HT-29 and COLO-205 cells were treated CEP and cell cycle was analyzed by PI staining followed by flow cytometry. As shown in Fig. 2A, the percentages of HT-29 cells in the G1 phase were significantly increased following treatment with $10 \mu \mathrm{M}$ CEP for $12 \mathrm{~h}$. Similar results were detected in HT-29 cells treated with 5 and $10 \mu \mathrm{M} \mathrm{CEP}$ for $24 \mathrm{~h}$. However, it should be noted that $20 \mu \mathrm{M}$ of CEP significantly increased accumulation of the sub-G1 fraction, an indicator of apoptotic cell death. At $36 \mathrm{~h}$ of incubation, treatment with CEP only at $5 \mu \mathrm{M}$ caused cell accumulation at the G1 phase whereas 10 and $20 \mu \mathrm{M}$ of CEP significantly induced a sub-G1 accumulation 10- and 24-fold above control, respectively. We also observed a significant accumulation of COLO-205 cells in the G1/S phases following treatment with $\mathrm{CEP}$ at 10 and $20 \mu \mathrm{M}$ whereas CEP at $40 \mu \mathrm{M}$ induced apoptotic cell death as early as $12 \mathrm{~h}$ of incubation (Fig. 2B). Interestingly, for the longer incubation time-point, $\mathrm{CEP}$ at $10 \mu \mathrm{M}$ resulted in accumulation of the COLO-205 cells in $\mathrm{S}$ phase while apoptosis was significantly detected in the cells treated with CEP at 20 and $40 \mu \mathrm{M}$. These results indicated that CEP at low concentrations effectively disturbed cell cycle progression while CEP at higher concentrations clearly induced apoptosis in both HT-29 and COLO-205 cells.

Cepharanthine induces changes in cell cycle-regulated gene expression in colorectal cancer cells. To address the mechanism responsible for the effect of CEP on cell cycle arrest, we measured the mRNA levels of cell cycle regulators: cyclins A, D and E; and p21, a CDK inhibitor using real-time reverse transcription polymerase chain reaction. As shown in Fig. 3A, CEP at $20 \mu \mathrm{M}$ significantly decreased cyclin A mRNA level in HT-29 cells by $\sim 65 \%$. This compound also downregulated the expression of cyclin $\mathrm{D}$ in a concentration-dependent manner; however, expression of cyclin $\mathrm{E}$ was unaffected by CEP. Notably, the expression of $\mathrm{p} 21^{\text {Waf1/Cip } 1} \mathrm{mRNA}$ in 

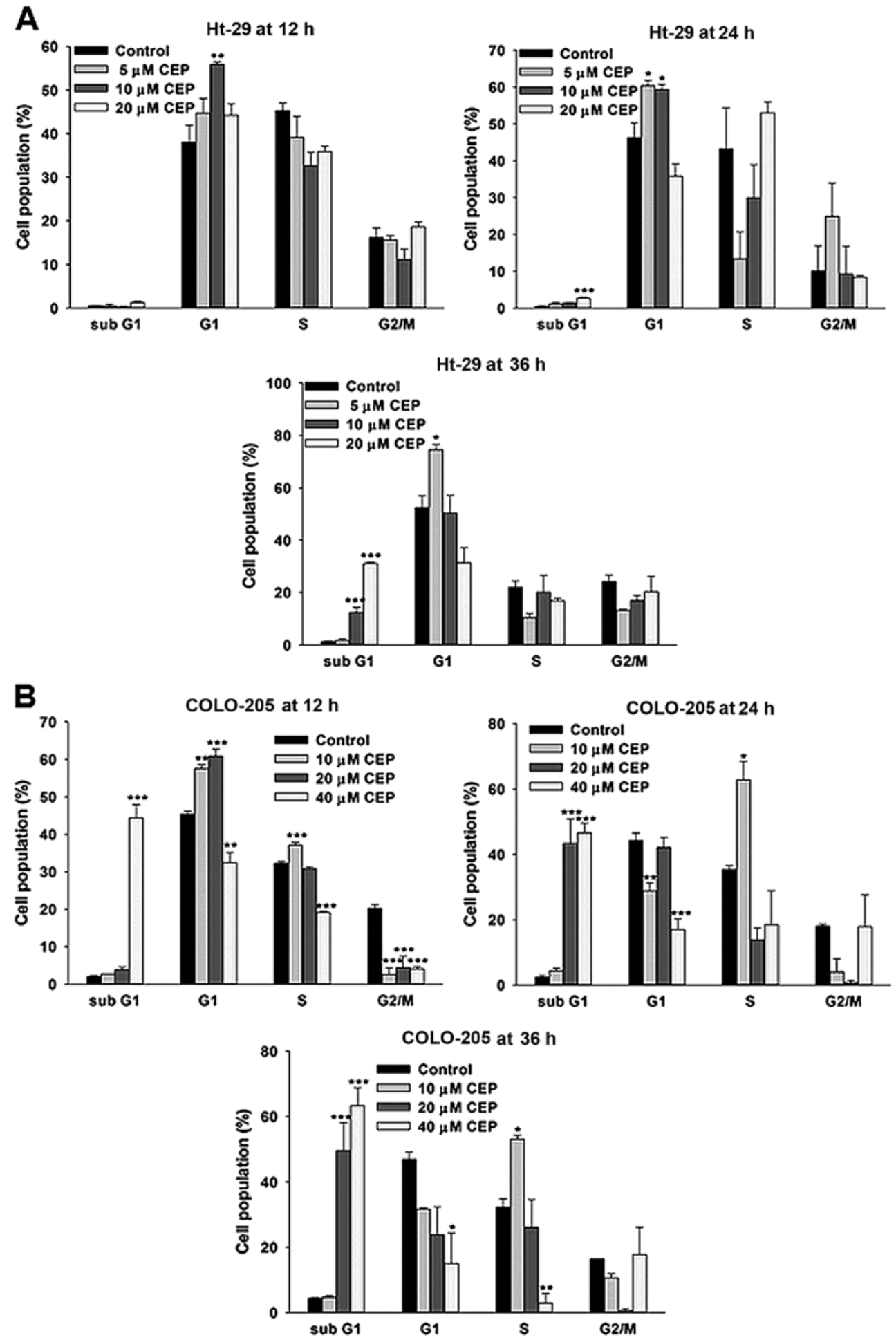

Figure 2. CEP induces cell cycle arrest and apoptosis in colorectal cancer cells. The percentage of cells with DNA content corresponding to sub-G1 fraction and G1, S and G2/M phases at 12, 24 and $36 \mathrm{~h}$ after CEP treatment on (A) HT-29 and (B) COLO-205 cells. ${ }^{*} \mathrm{p}<0.05,{ }^{* *} \mathrm{p}<0.01$ and ${ }^{* * * *} \mathrm{p}<0.001 \mathrm{vs}$. control.

HT-29 cells was dramatically upregulated in response to CEP treatment. CEP at 5, 10 and $20 \mu \mathrm{M}$ increased $21^{\text {Warl/Cipl }}$ mRNA levels $\sim 5,20$ and 60 times above control, respectively. In COLO-205 cells, CEP significantly downregulated the cyclin A mRNA expression levels in a concentration-dependent manner (Fig. 3B) whereas the expression of cyclin D and E were unaltered by CEP. Similar to HT-29, CEP at 20 and $40 \mu \mathrm{M}$ significantly induced the expression of $\mathrm{p} 21^{\text {Waf } 1 / \mathrm{Cipl}}$ mRNA in COLO-205 cells, although to a lesser extent.
Western blot analysis also showed that CEP suppressed expression of cyclin A2 and cyclin D1 proteins in HT-29 cells (Fig. 4A). Similarly, treatment with CEP resulted in a decrease in cyclin A2 protein level in COLO-205 cells in a concentration-dependent manner (Fig. 4B). The increased expressions of $\mathrm{p} 21^{\text {Waf } 1 / \text { Cip1 } 1}$ in HT-29 cells were further confirmed by immunofluorescence staining. HT-29 cells were treated with 5,10 and $20 \mu \mathrm{M}$ of CEP for $24 \mathrm{~h}$ then immunolabeled for the presence of $\mathrm{p} 21^{\text {Wafl/Cipl }}$ and stained with DAPI. 
A

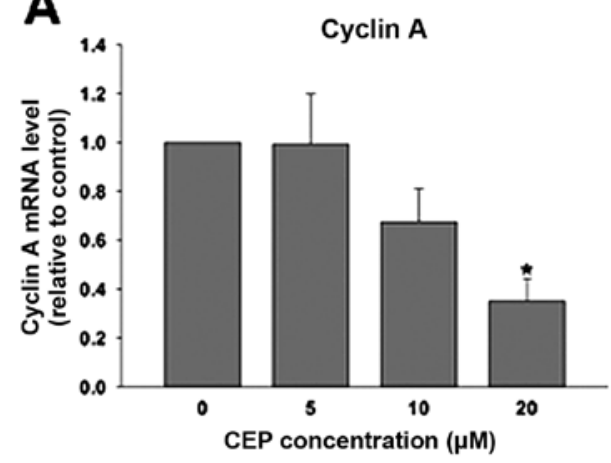

Cyclin E

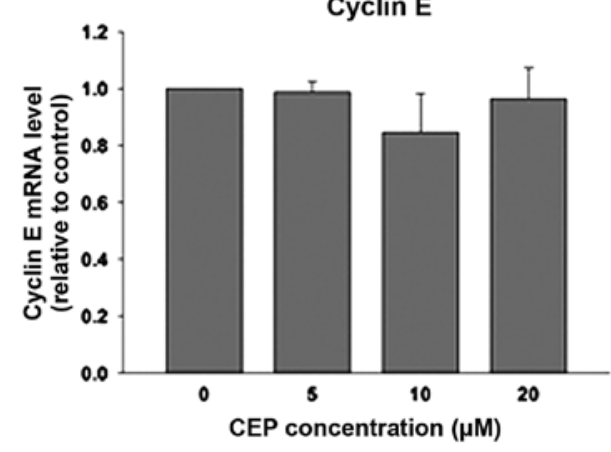

B

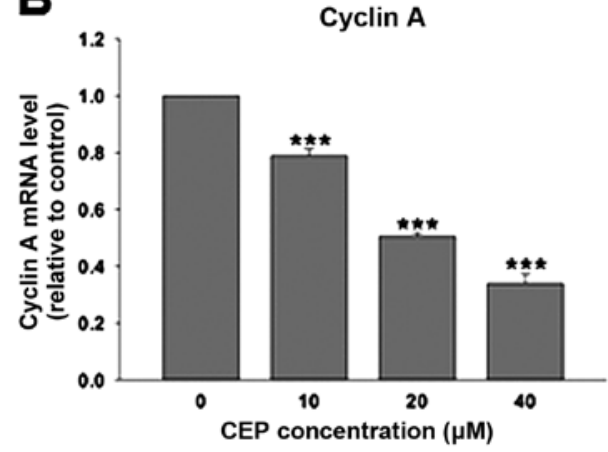

Cyclin E

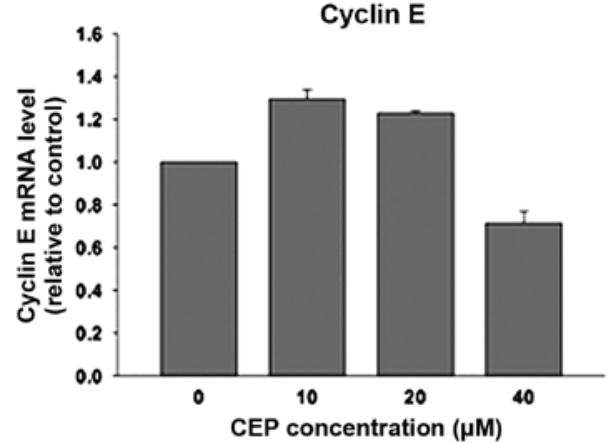

Cyclin D

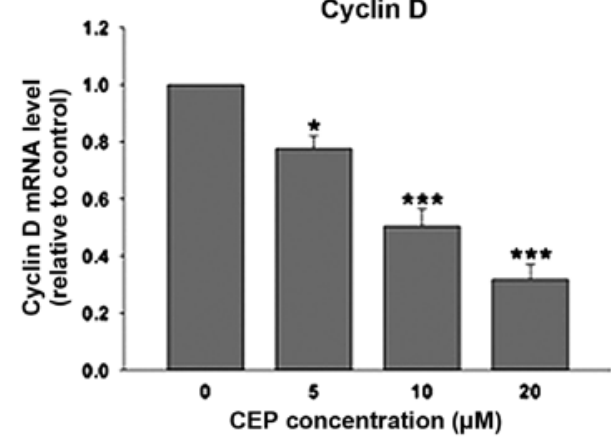

p21 Waticip1 $^{2}$

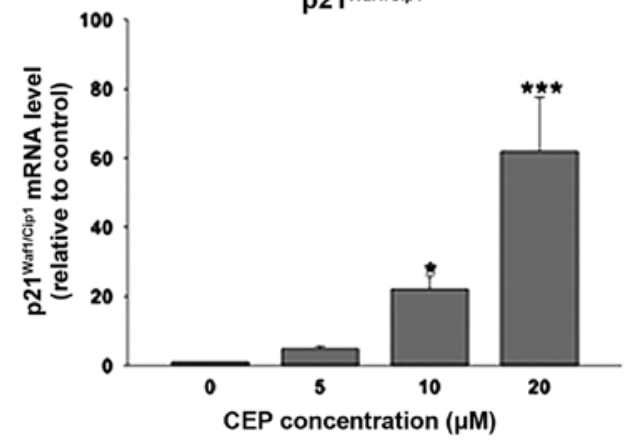

Cyclin D

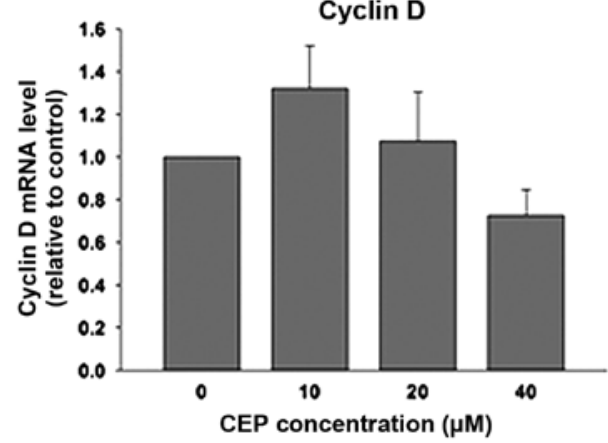

p21 Waf//Cip1

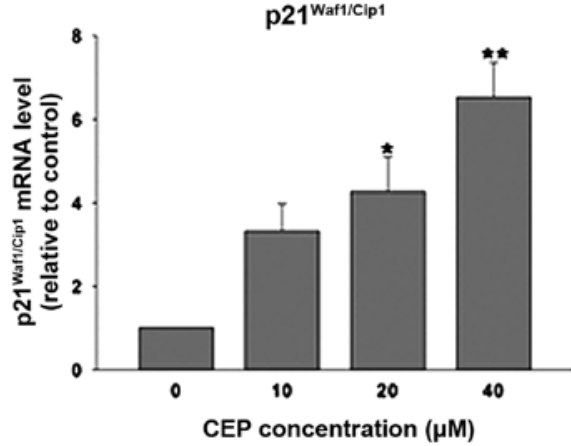

Figure 3. CEP downregulates the mRNA expression of cyclins and upregulates the mRNA expression of $\mathrm{p} 21^{\text {Wafl/Cipl }}$ in colorectal cancer cells. Cells were treated with CEP and the mRNA levels of cyclins A, D and E and p21 were determined in (A) HT-29 and (B) COLO-205 cells using real-time RT-PCR. "p<0.05, ${ }^{* *} \mathrm{p}<0.01$ and $^{* * * *} \mathrm{p}<0.001$ vs. control.

In agreement with mRNA and protein expression results, CEP increased $\mathrm{p} 21^{\text {Wafl/Cipl }}$ fluorescence intensity in the nucleus of the HT-29 cells in a concentration-dependent manner (Fig. 5).

Cepharanthine decreases Bcl-2 expression in colorectal cancer cells. The intrinsic pathway of apoptosis is mainly involved in anticancer activity of several chemotherapeutic agents. This pathway is regulated by members of the $\mathrm{Bcl}-2$ family proteins (27). Therefore the mRNA levels of Bcl-2 family, such as anti-apoptotic proteins, including Bcl-2 and $\mathrm{Bcl}-\mathrm{xl}$; and pro-apoptotic proteins, including Bax and Bak were evaluated after CEP treatment. Real-time RT-PCR analysis revealed that CEP at $20 \mu \mathrm{M}$ significantly downregulated the mRNA expression of anti-apoptotic proteins, $\mathrm{Bcl}-2$ and Bcl-xl in HT-29 cells (Fig. 6A). In contrast, CEP did not alter mRNA expression of pro-apoptotic proteins, Bak and Bax. 

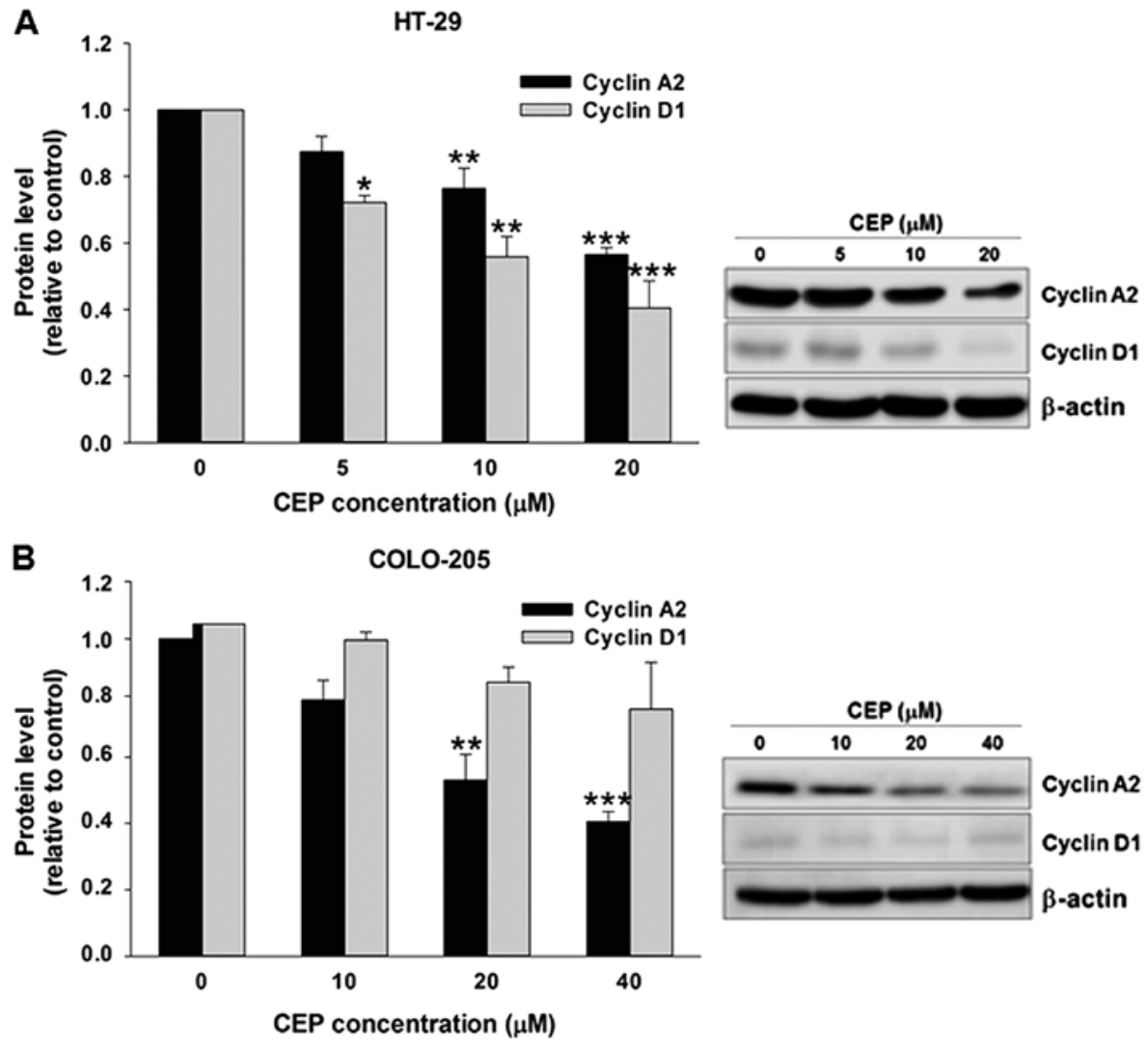

Figure 4. CEP downregulates the protein expression of cyclins in colorectal cancer cells. Cells were treated with CEP and the protein levels of cyclins A2 and D1 were determined in (A) HT-29 and (B) COLO-205 cells using western blot analysis. ${ }^{*} \mathrm{p}<0.05,{ }^{* *} \mathrm{p}<0.01$ and ${ }^{* * * *} \mathrm{p}<0.001$ vs. control.

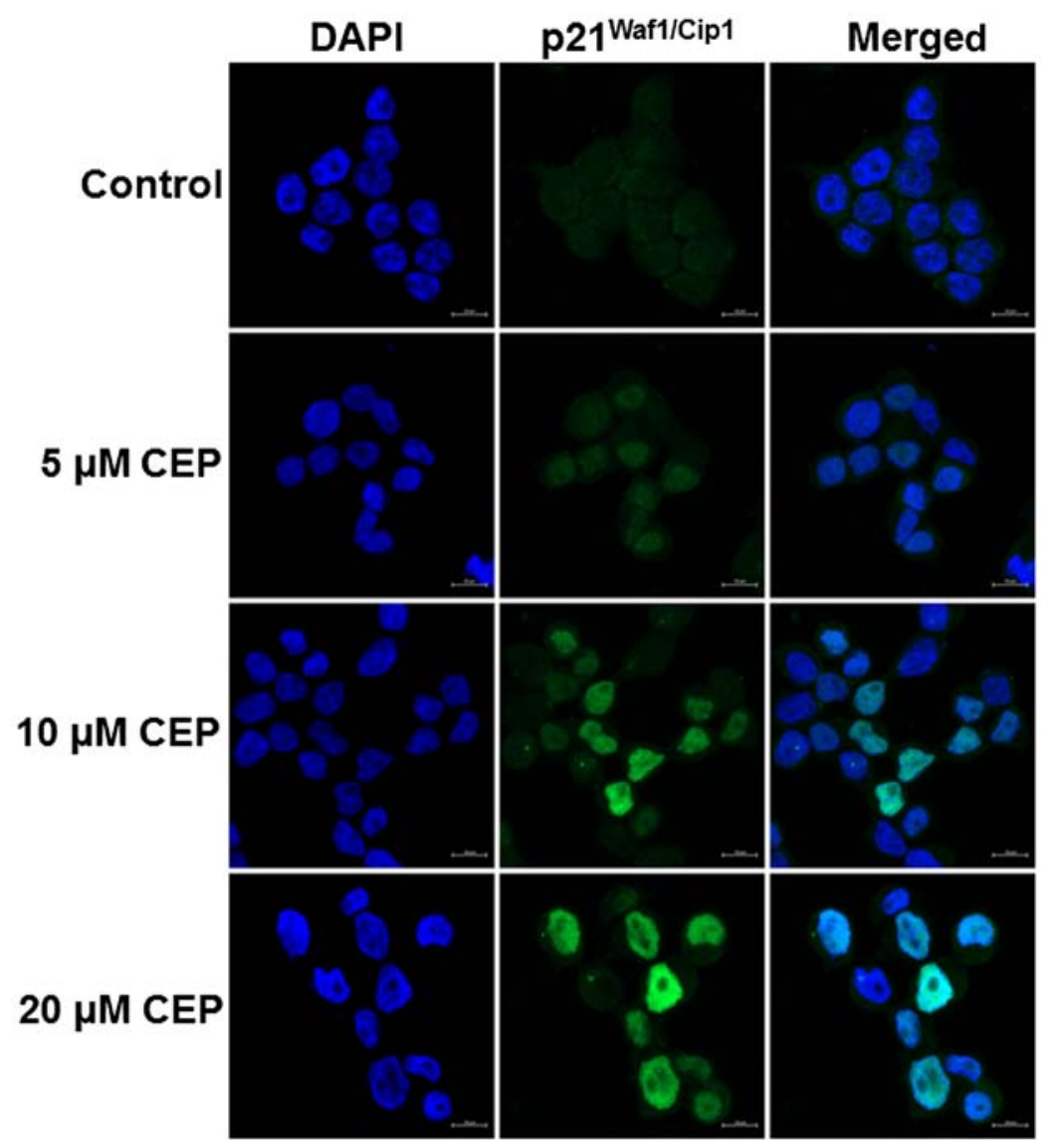

Figure 5. CEP induces $\mathrm{p} 21^{\text {wafl/Cipl }}$ intensity, especially in the nucleus of HT-29 cells. The immunofluorescence staining of HT-29 cells treated with CEP for $24 \mathrm{~h}$. The HT-29 cells were then immunolabeled for the presence of $\mathrm{p} 21^{\text {Waf1/Cipl }}$ and stained with DAPI. 

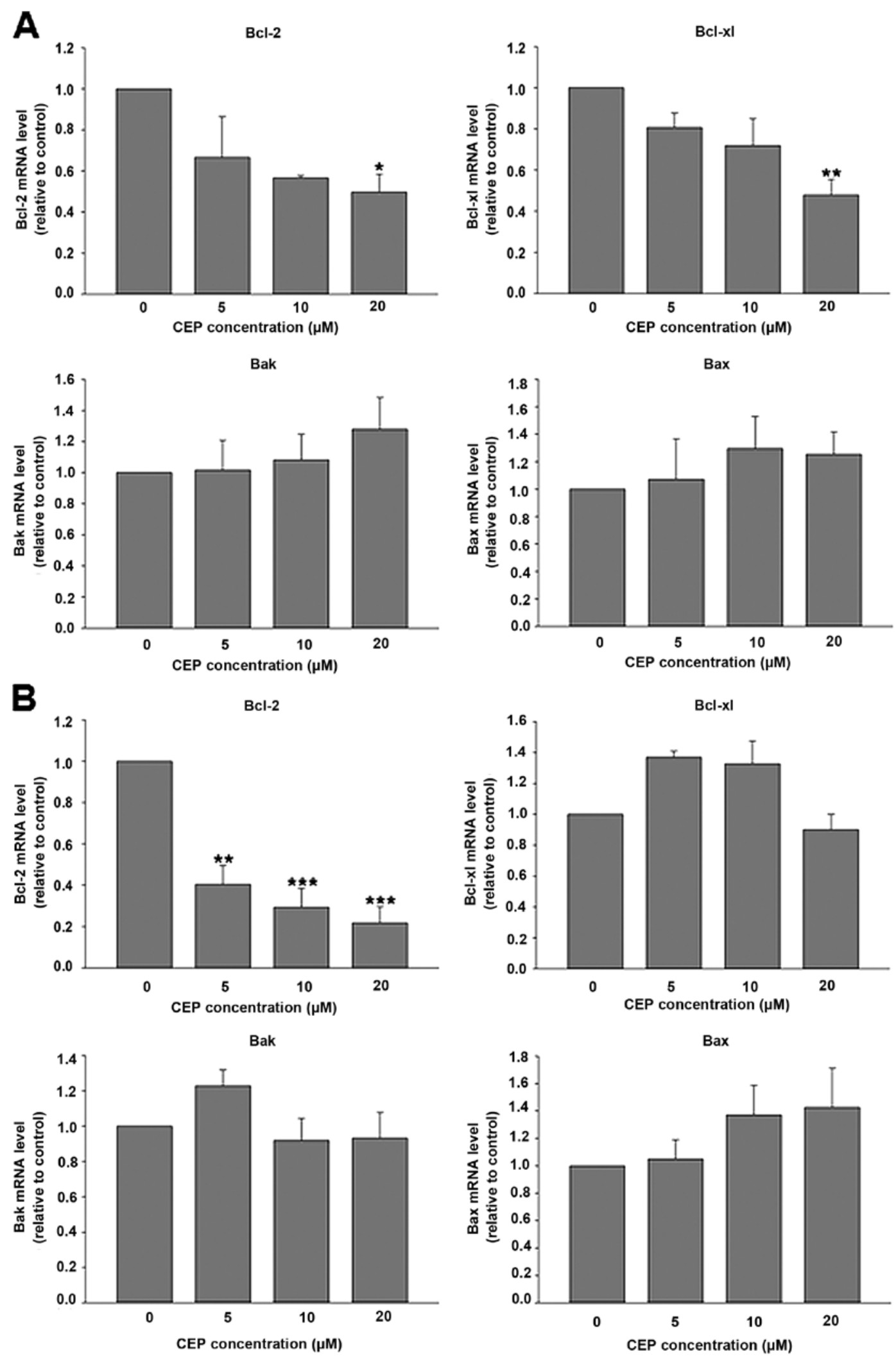

Figure 6. CEP downregulates the mRNA expression of $\mathrm{Bcl}-2$ and $\mathrm{Bcl}-\mathrm{xl}$ in colorectal cancer cells. Cells were treated with CEP and the mRNA levels of Bcl-2, Bcl-xl, Bak and Bax were determined in (A) HT-29 and (B) COLO-205 cells using real-time RT-PCR."p $<0.05,{ }^{* *}$ p $<0.01$ and ${ }^{* * *}$ p $<0.001$ vs. control.

As illustrated in Fig. 6B, CEP significantly decreased Bcl-2 mRNA expression in COLO-205 cells in a concentrationdependent manner. However, mRNA levels of Bcl-xl, Bak and Bax were unaffected following CEP treatment. These results indicated that downregulation of Bcl-2 mRNA expression was likely responsible for CEP-induced apoptosis in colorectal cancer cells.

Cepharanthine induces ROS production in colorectal cancer cells. Overproduction of reactive oxygen species (ROS) can 
A

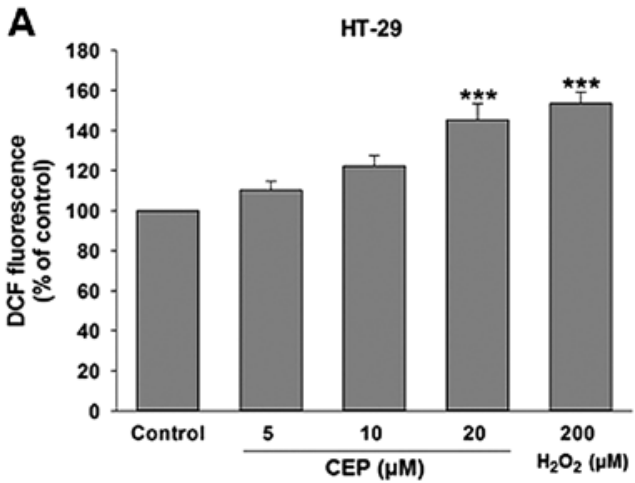

C

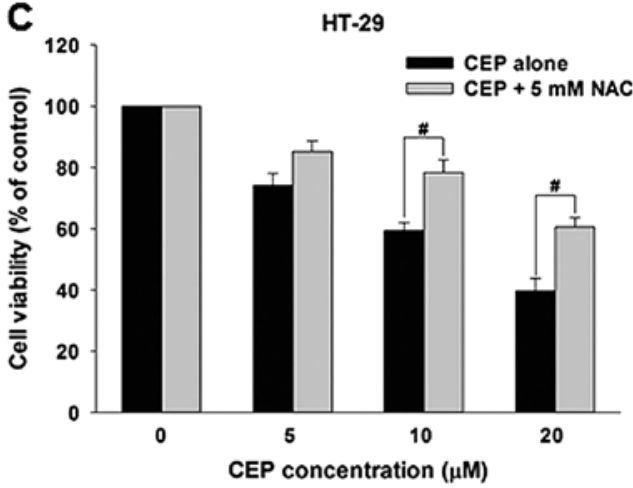

B

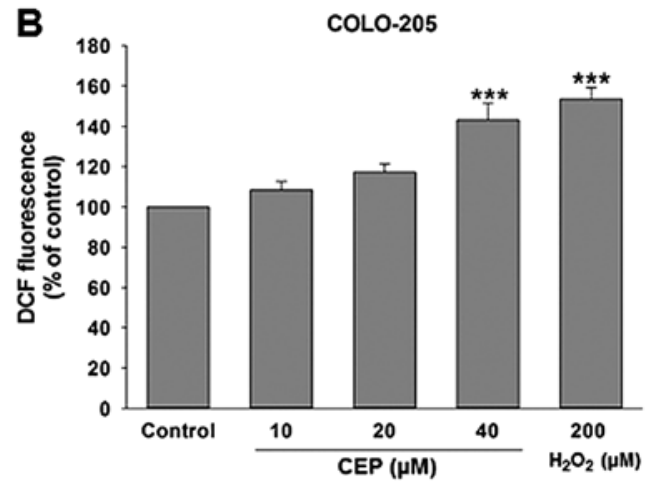

D

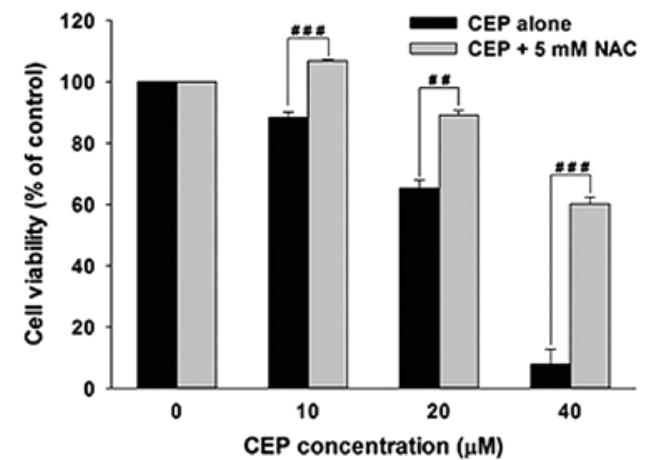

Figure 7. CEP induces ROS generation in colorectal cancer cells. The ROS levels (DCF fluorescence intensity) in (A) HT-29 and (B) COLO-205 cells were measured by dichlorodihydrofluorescein diacetate (DCFH-DA) assay following CEP treatment. The viability of (C) HT-29 and (D) COLO-205 cells treated without NAC vs. with NAC, prior to CEP treatment. ${ }^{* * *} \mathrm{p}<0.001$ vs. control. ${ }^{\#} \mathrm{p}<0.05,{ }^{\#} \mathrm{p}<0.01$ and ${ }^{\# \#} \mathrm{p}<0.001$ vs. CEP alone.
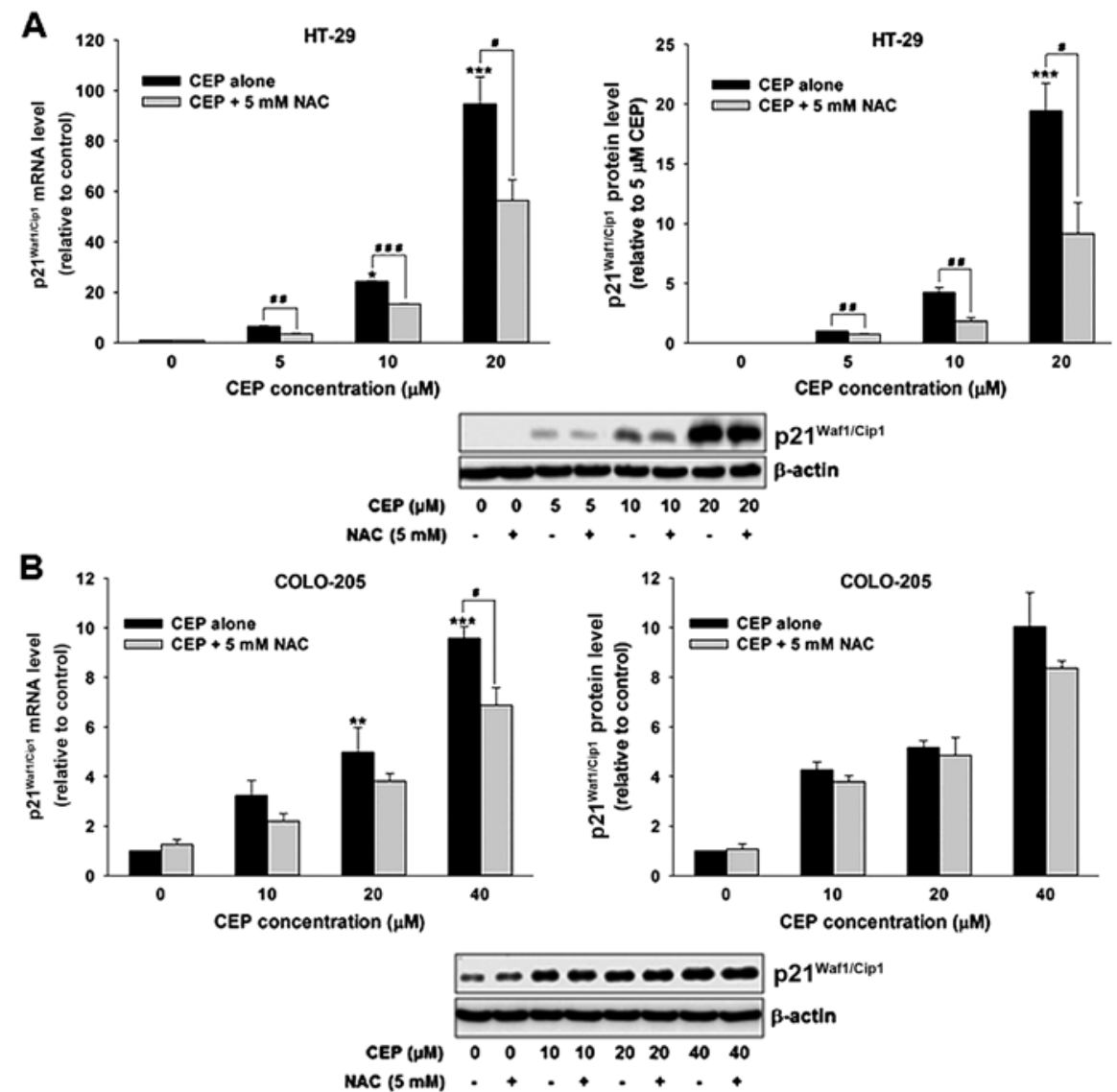

Figure 8. CEP induces $\mathrm{p} 21^{\mathrm{Waf} 1 / \mathrm{Cipl}}$ expression via ROS production in p53 mutant colorectal cancer cells. Cells were treated with CEP in the absence or presence of NAC for $24 \mathrm{~h}$. The mRNA and protein levels of p2 ${ }^{\text {Waf1/Cip1 }}$ were measured in (A) HT-29 and (B) COLO-205 cells. ${ }^{*}$ p $<0.05,{ }^{* *}$ p $<0.01$, and ${ }^{* * *}$ p $<0.001$ vs. control. ${ }^{\#} \mathrm{p}<0.05,{ }^{\#} \mathrm{p}<0.01$ and ${ }^{\# \#} \mathrm{p}<0.001$ vs. CEP alone. 
lead to oxidative stress causing cell death. It has been shown that various anticancer drugs such as cisplatin, vinblastin, doxorubicin and camptothecin induce cell death through generation of ROS in several cancer cells (28). We therefore determined whether CEP is capable of triggering ROS production in colorectal cancer cells. HT-29 cells were treated with CEP at concentrations of 5, 10 and $20 \mu \mathrm{M}$ and COLO-205 cells were treated with CEP at concentrations of 10,20 and $40 \mu \mathrm{M}$. One hour after treatment ROS level was determined by measuring the dichlorodihydrofluorescein (DCF) fluorescence intensity with dichlorodihydrofluorescein diacetate (DCFH-DA) assay. As illustrated in Fig. 7A, treatment of HT-29 cells with 10 and $20 \mu \mathrm{M}$ of CEP significantly induced ROS production. Similarly, ROS level was significantly elevated in COLO-205 cells after treatment with $40 \mu \mathrm{M}$ of CEP (Fig. 7B).

To confirm whether ROS production is involved in CEP-mediated cytotoxicity, both HT-29 and COLO-205 cells were pre-incubated with $5 \mathrm{mM}$ of $\mathrm{N}$-acetyl cysteine (NAC), a ROS inhibitor, for $30 \mathrm{~min}$ before treatment with CEP. As shown in Fig. 7C and D, the cytotoxicity of CEP to both HT-29 and COLO-205 cells was significantly reduced by pretreatment with NAC, suggesting that ROS production is partly responsible for CEP-induced colorectal cancer cell death.

Many studies have reported links between ROS and $\mathrm{p} 21^{\text {Waf } 1 / \text { Cip1 }}$, we therefore determined whether ROS is involved in the induction of $\mathrm{p} 21^{\text {Waf1/Cip } 1}$ following CEP treatment in colorectal cancer cells. As shown in Fig. 8A, CEP increased p $21^{\text {Waf1/Cip1 }}$ expression on the mRNA and protein levels in HT-29 cells. Remarkably, co-incubation with NAC significantly attenuated the $\mathrm{p} 21^{\text {Waf } 1 / \text { Cip } 1}$ induction in CEP-treated cells. Although treatment with CEP resulted in upregulation of $\mathrm{p} 21^{\text {Waf1/Cip1 }} \mathrm{mRNA}$ and protein levels in COLO-205, the significant difference in $\mathrm{p} 21^{\mathrm{Waf} 1 / \mathrm{Cip} 1} \mathrm{mRNA}$ level between cells treated with CEP alone and in combination with NAC was only detected after treatment with $40 \mu \mathrm{M}$ CEP (Fig. 8B). Taken together, these results suggest that ROS is critically required for $\mathrm{p} 21^{\mathrm{Waf} 1 / \mathrm{Cip} 1}$ induction in response to CEP treatment in p53 mutant colorectal cancer cells.

\section{Discussion}

Many lines of evidence have demonstrated that p53 mutations, the most common genetic change identified in human cancer, are associated with resistance to several types of chemotherapeutic agents, including alkylating agents, topoisomerase I/II inhibitors, and antimetabolites (29-31). This highlights the need for a novel anticancer agent that remains effective in cancer cells harboring mutant p53. Cepharanthine (CEP), a biscoclaurine alkaloid isolated from Stephania cepharantha Hayata, was shown to possess anticancer activities in many types of cancer cells (11-21). Interestingly, it was reported that CEP could inhibit the growth of human adenosquamous cell carcinoma containing p53 mutation (25). In the present study, we investigated the anticancer activity of CEP against colorectal cancer cells using a p53 wild-type human colorectal cancer cell line, COLO-205, and a p53 mutant human colorectal cancer cell line, HT-29. We have found that CEP induced colorectal cancer cell death in vitro in a time- and concentration-dependent manner. Interestingly, CEP was more cytotoxic to the p53 mutant HT-29 cells than the p53 wild-type COLO205 cells. The $\mathrm{IC}_{50}$ value of the HT-29 cells treated with CEP was 4 times lower than that in the COLO-205 cells. In contrast, the commonly used chemotherapeutic agents, 5-FU, oxaliplatin and SN-38, an active metabolite of irinotecan were more cytotoxic to the COLO-205 cells than the HT-29 cells. In addition to approved drugs, promising chemotherapeutic agents such as 3'-hydroxypterostilbene, 3,5,4'-trimethoxystilbene, and myricetin (32-34) were shown to be more toxic to the COLO-205 cells than the HT-29 cells.

To further confirm the anticancer activity of CEP against p53 mutant colorectal cancer cells, SW-620, another p53 mutant colorectal cancer cell line and HCT-116, a p53 wild-type colorectal cancer cell were treated with CEP. The MTT assays revealed that CEP was more cytotoxic to the two p53 mutant colorectal cancer cell lines, HT-29 and SW-620, than the two p53 wild-type colorectal cancer cell lines, HCT-116 and COLO-205, suggesting that CEP has potential to be used as a novel chemotherapeutic agent for colorectal cancer cells harboring p53 mutation.

Many chemotherapeutic agents exert their anticancer activity via induction of cell cycle arrest and apoptosis. Previous studies demonstrated that CEP could induce cell cycle arrest at G1 and S phase in various types of cancer $(13,15,18)$. Similar to previous studies, we have found that CEP caused accumulation of HT-29 and COLO-205 cells at the G1 and the G1 and S phase of the cell cycle, respectively. Remarkably, cell cycle arrest effect was detected following CEP treatment at the lowest concentration while its apoptotic-induction effect was noted at the highest concentration in both HT-29 and COLO-205 cells. The time course studies revealed that CEP at the intermediate concentration $(10 \mu \mathrm{M})$ significantly caused accumulation of the HT-29 cells at the G1 phase after 24-h treatment and induced apoptosis at $36 \mathrm{~h}$ whereas treatment of COLO-205 cells with CEP at the intermediate concentration $(20 \mu \mathrm{M})$ significantly disrupted progression of cell cycle as early as $12 \mathrm{~h}$ while significant apoptotic cell death was observed at $24 \mathrm{~h}$ after treatment. These results suggested that CEP was able to induce both cell cycle arrest and apoptosis and its anticancer activity likely depended on concentration and duration of the treatment. Accumulating evidence has demonstrated that mutations of p53 are capable of not only disrupting the antiproliferative properties but also promoting various oncogenic responses to cell growth, metastasis, invasion, chemoresistance, and apoptosis resistance (5). Moreover, it was reported that mutant p53 could delay cell growth arrest in fibroblasts (35). Thus, it is likely that mutation of p53 is responsible for the delayed cell cycle arrest in HT-29 cells relative to COLO-205 cells.

Bcl-2 family proteins, including anti-apoptotic proteins such as Bcl-2 and Bcl-xl and pro-apoptotic proteins such as Bax and Bak are regulators of mitochondria or intrinsic apoptotic pathway (36). It has been reported that CEP induced apoptosis through upregulation of Bax and downregulation of Bcl-2 and Bcl-xl in various cancer cells $(18,19,21)$. In agreement with these observations, this study revealed that CEP decreased level of Bcl-2 mRNA in COLO-205 cells in a concentrationdependent manner. Notably, significant reductions of mRNA levels of the two key anti-apoptotic proteins, Bcl-2 and Bcl-xl were observed in HT-29 cells following CEP treatment at high 
concentration only. Taken together, these results suggested that apoptotic-inducing effect of CEP was mediated through downregulation of Bcl-2 and Bcl-xl in colorectal cancer cells. Previously, several studies demonstrated that CEP reduced expression of Bcl-2 and Bcl-xl through inhibition of STAT3 signaling pathway in cervical adenocarcinoma and osteosarcoma $(18,19)$. Therefore, apoptosis-inducing effects of CEP on human colorectal cancer cells may be mediated through inhibition of STAT3 resulting in suppression of downstream gene products, including Bcl-2 and Bcl-xl. However, the effects of CEP on the STAT3 signaling pathway in colorectal cancer cells require further elucidation.

The cell cycle is regulated at the checkpoints by cyclin/cyclin-dependent kinase (CDK) complexes, which are inactivated by CDK inhibitors (CKIs) (37). In the present study, we have documented that CEP downregulated the expression of cyclin A and both cyclin A and D in COLO-205 and HT-29 cells, respectively. Numerous previous studies demonstrated that CEP downregulated the expression of cyclins D1 and $\mathrm{E}$ in several cancer cells including osteosarcoma, oral squamous cell carcinoma and myeloma $(13,15,18)$. However, one of the most surprising finding of this study was that CEP was able to decrease the expression of cyclin A in both COLO-205 and HT-29 cells, suggesting that cyclin A may be a therapeutic target of CEP in human colorectal cancer cells.

Oxidative stress is an overproduction of reactive oxygen species (ROS) beyond the cellular antioxidant capacity. It was reported that oxidative stress can trigger p53-dependent and p53-independent apoptotic cell death pathway in cancer cells (38). Numerous natural agents with potent anticancer activity such as epigallocatechin-3-gallate (EGCG), resveratrol, and curcumin were shown to induce apoptosis in cancer cells via a ROS-dependent pathway (39). Previous studies demonstrated that CEP triggered apoptosis in human hepatocellular carcinoma cells and non-small cell lung cancer cells through ROS (14,21). Similarly, the results of this study showed that CEP significantly increased ROS level in HT-29 and COLO-205 cells. Moreover, the cytotoxicity of CEP was significantly abolished by $\mathrm{N}$-acetylcysteine (NAC), a specific ROS inhibitor, indicating that cytotoxic effect of CEP is partly mediated by ROS.

Although p53 is a known transcriptional regulator of p21 Waf1/Cip1 , several different compounds such as phenoxodiol, ascofuranone, and MLN4924, an inhibitor of NEDD8 activating enzyme, have been demonstrated to induce p2 $1^{\text {Waf1/Cip1 }}$ independently of p53 status (40-42). Similarly, CEP was shown to induce cell cycle arrest at G1 phase by activating $\mathrm{p} 21^{\mathrm{Waf} 1 / \mathrm{Cip} 1}$ in a human adenosquamous cell carcinoma cell line harboring mutant p53 (25). Our results also showed that CEP dramatically increased mRNA and protein levels of p21 $1^{\text {Waf1/Cipl } 1}$ in HT-29 cells. Remarkably, NAC was able to attenuate CEP-induced $\mathrm{p} 21^{\text {Waf1/Cip1 }}$ expression in HT-29 cells. Together, these findings suggest that upregulation of $\mathrm{p} 21^{\mathrm{Waf} 1 / \mathrm{Cip} 1}$ by $\mathrm{ROS}$ mainly contribute to anticancer activity of CEP in p53 mutant colorectal cancer cells. Although several studies demonstrated that upregulation of $\mathrm{p} 21^{\text {Waf1/Cip1 }}$ led to increased production of ROS in various cancer cells such as prostate, bladder and head and neck $(43,44)$, our results raised the possibility that CEP induced production of ROS, leading to transcription of $\mathrm{p} 21^{\text {Waf1/Cip1 }}$, independently of $\mathrm{p} 53$. The high levels of $\mathrm{p} 21^{\mathrm{Waf1} / \mathrm{Cip} 1}$, in turn, activated ROS production. A recent study demonstrated that cells undergoing p21 Waf1/Cip1 dependent cell death had higher sensitivity to oxidants (43), thus it is likely that upregulation of $\mathrm{p} 21^{\text {Waf1/Cip1 }}$ makes HT-29 cells susceptible to cytotoxicity of CEP. In the present study, we also uncovered that CEP increased $\mathrm{p} 21^{\text {Waf1/Cip1 }}$ in COLO-205 cells but less extensive than in HT-29 cells and NAC had no significant effect on CEP-induced $\mathrm{p} 21^{\text {Waf1/Cip1 }}$ expression. Since p53 regulates growth arrest and apoptosis mainly through the activation or suppression of various target genes, therefore expression of $\mathrm{p} 21^{\text {Waf1/Cip } 1}$ might not play an important role in anticancer activity of CEP in p53 wild-type colorectal cancer cells. In fact, we observed that CEP dramatically downregulated Bcl-2 expression in COLO-205 cells.

In conclusion, these results clearly illustrated that CEP has a remarkable anticancer activity against both p53 wild-type and p53 mutant colorectal cancer cells. Mechanistic studies revealed that the anticancer effect of CEP in colorectal cancer cells involves induction of cell cycle arrest and apoptosis which may be associated with upregulation of $\mathrm{p} 21^{\text {Waf1/Cip1 }}$, downregulation of cyclin A and Bcl-2 and induction of ROS. It should be noted, however, that this study was only performed on two cell lines. Further elucidation and verification of these observations both in vitro and in vivo are warranted. In addition, toxicity of CEP should be thoroughly tested for clinical application.

\section{Acknowledgements}

We thank Dr Amornpun Sereemaspun at the Department of Anatomy, Faculty of Medicine, Chulalongkorn University for kindly providing SW-620 and COLO-205 cell lines and Mr. Noppadol Saardlam at the Immunology Laboratory, Faculty of Dentistry, Chulalongkorn University for flow cytometric analysis. This study was supported by the 90th Anniversary of Chulalongkorn University Fund (Ratchadaphiseksompot Endowment Fund), grant no. GCUGR11255725066M (A.R.), Thailand Research Fund, grants no. TGR5880214 (A.M.) and TRG5880242 (P.W.), Rathchadaphiseksomphot Endowment Fund for Development of New Faculty Staff, grant no. GDNS 59-007-30-001 (P.W.), the Chulalongkorn Academic Advancement into its 2nd Century (CUAASC) Project and Special Task Force for Activating Research (STAR) Ratchadaphiseksomphot Endowment Fund, grant no. GSTAR 59-005-30-001.

\section{References}

1. O'Keefe SJ: Diet, microorganisms and their metabolites, and colon cancer. Nat Rev Gastroenterol Hepatol 13: 691-706, 2016.

2. Kotelevets L, Chastre E, Desmaële D and Couvreur P: Nanotechnologies for the treatment of colon cancer: From old drugs to new hope. Int J Pharm 514: 24-40, 2016.

3. $\mathrm{Hu} \mathrm{T}$, Li Z, Gao CY and Cho CH: Mechanisms of drug resistance in colon cancer and its therapeutic strategies. World J Gastroenterol 22: 6876-6889, 2016.

4. Takayama T, Miyanishi K, Hayashi T, Sato Y and Niitsu Y: Colorectal cancer: Genetics of development and metastasis. J Gastroenterol 41: 185-192, 2006.

5. Muller PA and Vousden KH: p53 mutations in cancer. Nat Cell Biol 15: 2-8, 2013.

6. He C, Li L, Guan X, Xiong L and Miao X: Mutant p53 gain of function and chemoresistance: The role of mutant $\mathrm{p} 53$ in response to clinical chemotherapy. Chemotherapy 62: 43-53, 2017. 
7. Dart DA, Picksley SM, Cooper PA, Double JA and Bibby MC: The role of $\mathrm{p} 53$ in the chemotherapeutic responses to cisplatin, doxorubicin and 5-fluorouracil treatment. Int J Oncol 24: $115-125,2004$

8. Ravi R, Jain AJ, Schulick RD, Pham V, Prouser TS, Allen H, Mayer EG, Yu H, Pardoll DM, Ashkenazi A, et al: Elimination of hepatic metastases of colon cancer cells via p53-independent cross-talk between irinotecan and Apo2 ligand/TRAIL. Cancer Res 64: 9105-9114, 2004.

9. Arango D, Wilson AJ, Shi Q, Corner GA, Arañes MJ, Nicholas C, Lesser M, Mariadason JM and Augenlicht LH: Molecular mechanisms of action and prediction of response to oxaliplatin in colorectal cancer cells. Br J Cancer 91: 1931-1946, 2004.

10. Rogosnitzky M and Danks R: Therapeutic potential of the biscoclaurine alkaloid, cepharanthine, for a range of clinical conditions. Pharmacol Rep 63: 337-347, 2011

11. Wu J, Suzuki H, Zhou YW, Liu W, Yoshihara M, Kato M, Akhand AA, Hayakawa A, Takeuchi K, Hossain K, et al: Cepharanthine activates caspases and induces apoptosis in Jurkat and K562 human leukemia cell lines. J Cell Biochem 82 200-214, 2001

12. Wu J, Suzuki H, Akhand AA, Zhou YW, Hossain K and Nakashima I: Modes of activation of mitogen-activated protein kinases and their roles in cepharanthine-induced apoptosis in human leukemia cells. Cell Signal 14: 509-515, 2002.

13. Harada K, Supriatno, Yamamoto S, Kawaguchi S, Yoshida $H$ and Sato M: Cepharanthine exerts antitumor activity on oral squamous cell carcinoma cell lines by induction of $\mathrm{p} 27^{\mathrm{Kip} 1}$. Anticancer Res 23B: 1441-1448, 2003.

14. Biswas KK, Tancharoen S, Sarker KP, Kawahara K, Hashiguchi T and Maruyama I: Cepharanthine triggers apoptosis in a human hepatocellular carcinoma cell line (HuH-7) through the activation of JNK1/2 and the downregulation of Akt. FEBS Lett 580: 703-710, 2006

15. Kikukawa Y, Okuno Y, Tatetsu H, Nakamura M, Harada N, Ueno S, Kamizaki Y, Mitsuya $\mathrm{H}$ and Hata $\mathrm{H}$ : Induction of cell cycle arrest and apoptosis in myeloma cells by cepharanthine, a biscoclaurine alkaloid. Int J Oncol 33: 807-814, 2008.

16. Seubwai W, Vaeteewoottacharn K, Hiyoshi M, Suzu S, Puapairoj A, Wongkham C, Okada S and Wongkham S: Cepharanthine exerts antitumor activity on cholangiocarcinoma by inhibiting NF-kappaB. Cancer Sci 101: 1590-1595, 2010.

17. Uthaisar K, Seubwai W, Srikoon P, Vaeteewoottacharn K, Sawanyawisuth K, Okada S and Wongkham S: Cepharanthine suppresses metastatic potential of human cholangiocarcinoma cell lines. Asian Pac J Cancer Prev 13 (Suppl): 149-154, 2012.

18. Chen Z, Huang C, Yang YL, Ding Y, Ou-Yang HQ, Zhang YY and Xu M: Inhibition of the STAT3 signaling pathway is involved in the antitumor activity of cepharanthine in SaOS2 cells. Acta Pharmacol Sin 33: 101-108, 2012.

19. Fang ZH, Li YJ, Chen Z, Wang JJ and Zhu LH: Inhibition of signal transducer and activator of transcription 3 and cyclooxygenase- 2 is involved in radiosensitization of cepharanthine in HeLa cells. Int J Gynecol Cancer 23: 608-614, 2013.

20. Liu G, Wu D, Liang X, Yue H and Cui Y: Mechanisms and in vitro effects of cepharanthine hydrochloride: Classification analysis of the drug-induced differentially-expressed genes of human nasopharyngeal carcinoma cells. Oncol Rep 34: 2002-2010, 2015.

21. Hua P, Sun M, Zhang G, Zhang Y, Tian X, Li X, Cui R and Zhang X: Cepharanthine induces apoptosis through reactive oxygen species and mitochondrial dysfunction in human nonsmall-cell lung cancer cells. Biochem Biophys Res Commun 460: $136-142,2015$

22. Ebina T, Ishikawa $\mathrm{K}$ and Murata $\mathrm{K}$ : Antitumor effect of Cepharanthin in the double grafted tumor system. Gan To Kagaku Ryoho 17: 1165-1171, 1990 (In Japanese).

23. Takahashi-Makise N, Suzu S, Hiyoshi M, Ohsugi T, Katano H, Umezawa $\mathrm{K}$ and Okada S: Biscoclaurine alkaloid cepharanthine inhibits the growth of primary effusion lymphoma in vitro and in vivo and induces apoptosis via suppression of the NF-kappaB pathway. Int J Cancer 125: 1464-1472, 2009.
24. Harada K, Ferdous T, Itashiki Y, Takii M, Mano T, Mori Y and Ueyama Y: Cepharanthine inhibits angiogenesis and tumorigenicity of human oral squamous cell carcinoma cells by suppressing expression of vascular endothelial growth factor and interleukin-8. Int J Oncol 35: 1025-1035, 2009.

25. Harada K, Bando T, Yoshida $\mathrm{H}$ and Sato M: Characteristics of antitumour activity of cepharanthin against a human adenosquamous cell carcinoma cell line. Oral Oncol 37: 643-651, 2001.

26. Bun SS, Laget M, Chea A, Bun H, Ollivier E and Elias R: Cytotoxic activity of alkaloids isolated from Stephania rotunda [corrected]. Phytother Res 23: 587-590, 2009.

27. Brunelle JK and Letai A: Control of mitochondrial apoptosis by the Bcl-2 family. J Cell Sci 122: 437-441, 2009.

28. Fang J, Nakamura $\mathrm{H}$ and Iyer AK: Tumor-targeted induction of oxystress for cancer therapy. J Drug Target 15: 475-486, 2007.

29. Giaccone G and Pinedo HM: Drug Resistance. Oncologist 1: 82-87, 1996.

30. Vazquez A, Bond EE, Levine AJ and Bond GL: The genetics of the p53 pathway, apoptosis and cancer therapy. Nat Rev Drug Discov 7: 979-987, 2008.

31. Hientz K, Mohr A, Bhakta-Guha D and Efferth T: The role of p53 in cancer drug resistance and targeted chemotherapy. Oncotarget 8: 8921-8946, 2017.

32. Pan MH, Gao JH, Lai CS, Wang YJ, Chen WM, Lo CY, Wang M, Dushenkov S and Ho CT: Antitumor activity of 3,5,4'-trimethoxystilbene in COLO 205 cells and xenografts in SCID mice. Mol Carcinog 47: 184-196, 2008.

33. Cheng TC, Lai CS, Chung MC, Kalyanam N, Majeed M, Ho CT, Ho YS and Pan MH: Potent anti-cancer effect of 3'-hydroxypterostilbene in human colon xenograft tumors. PLoS One 9: e111814, 2014.

34. Ko CH, Shen SC, Lee TJ and Chen YC: Myricetin inhibits matrix metalloproteinase 2 protein expression and enzyme activity in colorectal carcinoma cells. Mol Cancer Ther 4: 281-290, 2005.

35. Wyllie F,Haughton M, Bartek J, Rowson J and Wynford-Thomas D: Mutant p53 can delay growth arrest and loss of CDK2 activity in senescing human fibroblasts without reducing p21(WAF1) expression. Exp Cell Res 285: 236-242, 2003.

36. Youle RJ and Strasser A: The BCL-2 protein family: Opposing activities that mediate cell death. Nat Rev Mol Cell Biol 9: 47-59, 2008.

37. Vermeulen K, Van Bockstaele DR and Berneman ZN: The cell cycle: A review of regulation, deregulation and therapeutic targets in cancer. Cell Prolif 36: 131-149, 2003.

38. Shin SY,Ahn S, Koh D and Lim Y: p53-dependent and-independent mechanisms are involved in (E)-1-(2-hydroxyphenyl)-3-(2methoxynaphthalen-1-yl)prop-2-en-1-one (HMP)-induced apoptosis in HCT116 colon cancer cells. Biochem Biophys Res Commun 479: 913-919, 2016.

39. Mukhtar E, Adhami VM, Khan N and Mukhtar H: Apoptosis and autophagy induction as mechanism of cancer prevention by naturally occurring dietary agents. Curr Drug Targets 13: 1831-1841, 2012.

40. Jeong JH, Kang SS, Park KK, Chang HW, Magae J and Chang YC: p53-independent induction of G1 arrest and p2 $1^{\text {Waf } 1 / \text { Cipl }}$ expression by ascofuranone, an isoprenoid antibiotic, through downregulation of c-Myc. Mol Cancer Ther 9: 2102-2113, 2010.

41. Aguero MF, Venero M, Brown DM, Smulson ME and Espinoza LA: Phenoxodiol inhibits growth of metastatic prostate cancer cells. Prostate 70: 1211-1221, 2010

42. Jia L, Li H and Sun Y: Induction of p21-dependent senescence by an NAE inhibitor, MLN4924, as a mechanism of growth suppression. Neoplasia 13: 561-569, 2011.

43. Masgras I, Carrera S, de Verdier PJ, Brennan P, Majid A, Makhtar W, Tulchinsky E, Jones GD, Roninson IB and Macip S: Reactive oxygen species and mitochondrial sensitivity to oxidative stress determine induction of cancer cell death by $\mathrm{p} 21$. J Biol Chem 287: 9845-9854, 2012.

44. Fitzgerald AL, Osman AA, Xie TX, Patel A, Skinner H, Sandulache V and Myers JN: Reactive oxygen species and p2 $1^{\text {Waf1/Cipl }}$ are both essential for p53-mediated senescence of head and neck cancer cells. Cell Death Dis 6: e1678, 2015. 